\title{
UN MODELO DE CIUDADANÍA CON VIDA PROPIA. EL MILICIANO NACIONAL DURANTE LA PRIMERA MITAD DEL SIGLO XIX
}

\author{
A civic role-model with a life of its own. The national \\ militiaman during the first half of Spain's 19th century'
}

\author{
LOUISE ZBIRANSKI \\ Johann Wolfgang Goethe-Universität Frankfurt \\ LoviseZbiranski@hotmail.de
}

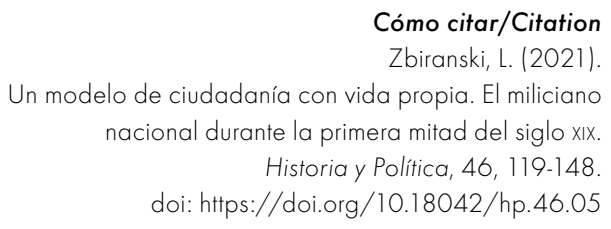

(Recepción: 09/06/2020; evaluación: 26/12/2020; aceptación: 11/02/2021; publicación: 30/11/2021)

\section{Resumen}

Durante el siglo XIX, el miliciano nacional fue tanto una figura de identificación para la ciudadanía como una de controversia política. Basándose en debates parlamentarios, panfletos, artículos de periódico y material de diversos archivos, este artículo detalla el debate sobre la figura del miliciano durante la primera mitad del siglo Xıx en España. La primera parte se centra en las primeras fases constitucionales (1812-1814 y 1820-1823) y muestra cómo la Milicia Nacional, inicialmente pensada como un actor abstracto de un sistema de contrapesos políticos, acabó cobrando vida propia gracias a las iniciativas ciudadanas. El miliciano se convirtió en un ideal ciudadano del liberalismo radical. La segunda parte, ubicada en los comienzos del

1 Traducido del inglés por Eric Jalain Fernández (Aeiou Traductores). 
reinado de Isabel II (1833-1844), subraya cómo los políticos denominados progresistas tińeron de emociones y radicalidad las imágenes asociadas a los milicianos para conquistar una posición dominante en los conflictos políticos de la época. No obstante, esa radicalización escapó a su control. Esta deriva demuestra, por un lado, que los discursos de la alta política y sus apropiaciones populares se reforzaban mutuamente y deja ver, por otro lado, cómo la imaginería ciudadana justificaba un expansivo abanico de actuaciones.

\title{
Palabras clave
}

Milicia Nacional; ciudadanía; ciudadanía armada; liberalismo; España.

\begin{abstract}
During the nineteenth century, the national militiaman was both a figure of civic identification and political controversy. By drawing on parliamentary debates, pamphlets, newspaper articles, and archive material, this article analyses the debate about the figure of the Militiaman during the first half of Spain's nineteenth century. Its first part focuses on Spain's early constitutional phase (1812-1814 and 1820-23). The National Militia, which was initially imagined as an abstract player in a system of checks-and balances, became alive through civic initiative. The Militiaman thus became a civic ideal of radical liberalism. The second part of this article centres on the early reign of Isabel II (1833-1844). It underlines how progresista politicians emotionalized and radicalized the images associated with the National Militiaman to conquer a dominant position in the political conflicts of the time. However, this radicalization could not be controlled. These results show, first, that high political discourse and its popular appropriations were mutually reinforcing factors and demonstrate, secondly, how civic imaginaries broadened the scope of justifiable actions.
\end{abstract}

\section{Keywords}

National Militia; citizenship; civic arming; liberalism; Spain. 
I. INTRODUCCION. II. MOMENTOS FUNDACIONALES. III. LOS ALBORES DE LA MILICIA. IV. LOS PRIMEROS AÑOS DEL REINADO DE ISABEL II. V. CONCLUSIÓN. BibLIOGRAFÍA.

\section{INTRODUCCION}

Desde la década de 1970 y con la publicación de la monografía de Juan Sisinio Pérez Garzón sobre la Milicia Nacional de Madrid, esta guardia cívica ha quedado estrechamente vinculada al debate sobre la vitalidad de la cultura política de la España del siglo xix. Pérez Garzón planteaba que, en contra de la intención de las élites, las clases bajas urbanas acabaron integrándose en la Milicia Nacional con el fin de desafiar a las jerarquías existentes ${ }^{2}$. Esto puso en tela de juicio la imagen apática de la población española habitual en otras obras clásicas del momento 3 .

La monografía de Pérez Garzón no solo demostró la relevancia de la guardia cívica, también estableció un paradigma de investigación sociohistórico que sigue predominando en los estudios sobre la Milicia ${ }^{4}$. Como consecuencia de ello, se ha prestado poca atención a los ideales políticos asociados a la Milicia y a su papel en la emergencia de nuevas ideas de ciudadanía 5 . Esta dejadez no deja de ser sorprendente, pues no solo las fechas de fundación y disolución de la Milicia (1812-1814 y 1874-1876) sugieren su estrecha conexión con el destino del liberalismo, sino que la tarea de protección del orden constitucional, que en ciertas fases recayó sobre la guardia, también subraya su papel central en la cultura política del siglo XIX.

Este artículo pretende, pues, reconstruir las imágenes de ciudadanía asociadas a la guardia cívica y destacar la especificidad de los primeros debates

Pérez Garzón (1978).

3 Tusell (1976) y Varela Ortega (1977). Para un cuestionamiento, Luján (2018).

4 Aunque estudios recientes prestan más atención a la relación de la Milicia con los ideales políticos, el marco propuesto por Pérez Garzón sigue dominando. Una síntesis de los estudios sobre el Trienio en Roca Vernet (2020). Para periodos posteriores, véanse: Chust (1987); Herrero Maté (2003); Naranjo Sanguino (2008); Portet i Pujol (2003), y Vallverdú i Martí (1989).

5 Sobre las ideas políticas asociadas a la Milicia, véase el breve pero instructivo análisis de: Fuentes (2002). 
liberales en torno a la Milicia Nacional entre 1808 y 1844. Para lograrlo, la investigación se basa en debates parlamentarios, panfletos, contribuciones periodísticas y material de archivo de dicho tiempo.

En torno a la guardia cívica interactuaron y se solaparon los debates parlamentarios y extraparlamentarios. Esta interacción ayudó a madurar una concepción activista de la ciudadanía que acabo convirtiéndose en un desafío incluso para el ala más radical del liberalismo parlamentario. La guardia cívica aparece así como un laboratorio de ciudadanía que, incluso en el ámbito discursivo, resultó ser mucho más independiente del liberalismo parlamentario de lo que suele sugerirse en la descripción de la Milicia Nacional como «brazo armado del partido progresista» ${ }^{6}$.

En las últimas décadas, los estudios histórico-culturales y conceptuales han demostrado que no basta reconstruir las ideas políticas partiendo únicamente de los textos canónicos, sino que hay que recurrir igualmente a panfletos, artículos periodísticos e incluso obras de teatro o comportamientos sociales. En comparación con la tradicional historia de las ideas, estos planteamientos han ampliado decisivamente la perspectiva: incluso si es cierto que dichas reconstrucciones siguen dominadas por el minoritario segmento de la población alfabetizada, la integración de textos menores saca a la luz un espectro de ideas y actores mucho más amplio. Basándose, pues, en fuentes heterogéneas, este artículo se alinea con este empeño. Pretende además vincularse a las pujantes investigaciones publicadas desde la década de 1990 sobre las diversas concepciones de ciudadanía del liberalismo español, sus diferencias internas y su respectivo declive ${ }^{8}$.

Resulta particularmente relevante en este sentido el concepto de ciudadano vigilante, reconstruido por María Cruz Romero a partir del discurso radical desarrollado durante el Trienio Liberal'. Según esta figura ideal del liberalismo temprano, los ciudadanos debían vigilar constantemente las actuaciones del Gobierno, con el fin de evitar abusos de poder. Así, los ciudadanos eran percibidos como "constantes e incansables atalayas de vigilancia de la Constitución». Puesto que el control del Gobierno y un activismo ciudadano autónomo desempeñaron un papel crucial en los discursos sobre la Milicia, este texto considera al miliciano como una materialización del ciudadano vigilante. Por tanto, la investigación de las imágenes idealizadas del miliciano nacional promete arrojar algo de luz sobre la emergencia y desarrollo de dicho ciudadano vigilante, sobre el cual poco se sabe aún.

\footnotetext{
Por ejemplo, Chordá et al. (2012):159f. Cita en p. 160.

Cabrera y Pro (2014).

Peyrou (2004); Romero (1998); Sierra (2000), y Pérez Ledesma (2007).

9 Romero (1993): 141f
} 
Una mejor comprensión de las imágenes idealizadas de la ciudadanía complementa los estudios de orientación sociohistórica sobre la Milicia. Y se trata de un paso relevante, que resuena con la investigación de fenómenos específicos de la Edad Contemporánea, como el nacionalismo, que ha demostrado que los conflictos y afinidades políticas no se derivan únicamente de las estructuras de clase. Surgen igualmente de la implicación emocional de los individuos y de identificaciones que puedan derivar del empleo de símbolos y rituales, pero también de la oferta de modelos atractivos, como puede resultar el del ciudadano en armas ${ }^{10}$. Una exploración de las variantes nacionales de esta figura (extraordinariamente popular en Europa, pero también en las Américas, a lo largo de todo el siglo XIX) puede ofrecer un punto de partida, así como un objeto de investigación concreto, para estudios comparativos sobre la cultura política de la época ${ }^{11}$.

\section{MOMENTOS FUNDACIONALES}

Cuando las Cortes se reunieron en Cádiz, resultó evidente a la gran mayoría de los diputados que la reorganización del Estado espańol pasaba por la reestructuración de sus fuerzas armadas ${ }^{12}$. No solo la así llamada guerra de la Independencia y las innovaciones militares de la Revolución francesa habían revelado los defectos del sistema de defensa, sino que ya varios filósofos y pensadores políticos de la Ilustración habían criticado el sistema tradicional según el cual el rey se arrogaba el control exclusivo sobre un Ejército permanente de soldados profesionales. En la España de la Edad Moderna, este Ejército podía recibir el respaldo de milicias provinciales y urbanas, para lo cual se movilizaba temporalmente a paisanos $^{13}$. La base de dicha movilización era su estatus de súbditos (en el caso de las milicias provinciales) o de "vecinos», es decir, de residentes privilegiados de las comunidades locales (en el caso de las milicias urbanas).

Pero como la organización de ambas milicias estaba marcada por exenciones y desigualdades sociales, tanto filósofos como economistas las tachaban de injustas e ineficientes. Además, pensadores políticos tan dispares como

10 Un análisis clásico sobre la importancia de los símbolos, García Pelayo (1964). Sobre el servicio militar como creador de identificaciones, Frevert (2004).

11 Chust y Marchena (2007) y Bergien y Pröve (2010).

12 Blanco Valdés (1988).

13 Sobre las Milicias Urbanas del siglo xvini, Corona Marzol (1999, 2001, 2009). Sobre periodos anteriores: Ruiz Ibáñez (1996, 2009). Sobre las milicias provinciales: Contreras Gay (1993) y Ońate Algueró (2001). 
Rousseau y el conde de Cabarrús coincidían en descalificar al Ejército permanente, acusándolo de ser un despilfarro de recursos y un instrumento de opre$\operatorname{sión}^{14}$. Y esta crítica de los intelectuales fue ganando terreno en la medida en que confluía con la resistencia popular a los procesos de reclutamiento forzado. Estos podían desencadenar "una tormenta de peticiones» ${ }^{15} \mathrm{o}$ incluso provocar episodios de resistencia armada, como fue el caso de Valencia en $1801^{16}$.

Para superar estas dificultades, filósofos, expertos en cuestiones castrenses y economistas abogaron por la introducción de un sistema militar más igualitario que algunos, como Condorcet, vieron representado en la tradición norteamericana de una ciudadanía armada ${ }^{17}$. El apoyo a una milicia igualitaria, sin embargo, tenía un tinte político, al menos desde los escritos de Rousseau: el filósofo no solo acuñó el famoso lema: «Todo ciudadano debe ser un soldado por deber, ninguno por profesión", sino que lo vinculó a la exigencia de establecer un Estado constitucional ${ }^{18}$.

Rousseau llegó incluso a plantear la existencia de una conexión profunda entre la fuerza de los hombres para luchar y su amor a la patria. A su parecer, el patriotismo solo podía existir si los defensores del país participaban también en su administración política. Si bien no todos los teóricos estaban de acuerdo con este planteamiento de Rousseau, muchos sí compartían su convicción de que los soldados necesitaban un vínculo emocional con la causa que defendían. Se dio por lo tanto un intenso debate en torno a cómo crear semejante vínculo, así como una creciente preocupación por el trato que recibían los soldados rasos del Ejército, derivando a cierta revalorización de estos ${ }^{19}$. Incluso se comenzó a desarrollar una glorificación y una idealización especifica de las virtudes del ciudadano-soldado ${ }^{20}$.

14 Las críticas de los ilustrados en Conze et al. (1978); Janssen (1982). Sobre las críticas de pensadores franceses que, según Reyes García Hurtado, resultaron cruciales en España: Hippler (2008) y Leonhard (2008): 113-131. Sobre su acogida en Espańa: García Hurtado (1997).

15 La cita es de Esdaile (2012). Sobre intentos populares de ayudar a los sorteados, Pérez Esteves (1976): 183-189.

16 Oñate Algueró (2001): 190. Sobre la resistencia a la quinta en general, Borreguero Beltrán (1989).

17 Condorcet (1788): 246, (1847): 42. Un autor español favorable a las milicias, Cabarrús (1813):143f.

18 Rousseau, Considerations sur le gouvernement de la Pologne et sur sa réformation projetée (1770-1771) (1971). Cit. p. 554.

19 Hippler (2008): 28-45. El artículo de García Hurtado (2010) contiene citas que ejemplifican un creciente interés en Espańa por los soldados rasos. Los catecismos militares apuntan en la misma dirección: Escoffet y de Matas (1807); De los Ríos (1792).

20 Aparte de Hippler (2008), véase también: Leonhard (2008): 113-131. 
En el debate en torno a la Constitución de Cádiz, la idea más radical en relación con este tema, es decir, la abolición del Ejército permanente, ni siquiera llegó a proponerse. Sin embargo, varios diputados consideraban que una profunda reforma tanto del armamento profesional como del no profesional podía reforzar al orden constitucional. De hecho, la Constitución de 1812 introducía un nuevo cuerpo armado: las milicias nacionales locales, una fuerza organizada con base provincial y de carácter civil y sobre la que la autoridad del rey era limitada ${ }^{21}$.

Las monografías dedicadas a la Milicia Nacional tienden a ser parcas en sus referencias a estos años fundacionales, puesto que los artículos constitucionales sobre la Milicia y la ley correspondiente aún cargaban con demasiadas reminiscencias de los antiguos modos de armar a los paisanos. La institución, además, nunca llegó a desarrollarse plenamente ${ }^{22}$ : pocas semanas después de la promulgación de la ley de las milicias nacionales locales en 1814, Fernando VII anulaba la Constitución.

Sin embargo, cuatro elementos convirtieron la guerra de la Independencia y los acontecimientos políticos de ella derivados en algo crucial para las posteriores controversias sobre la Milicia Nacional. Los debates de las Cortes sobre este cuerpo armado demuestran que, para empezar, ya en ese momento los políticos relacionaban la Milicia con una concepción radical del control al Gobierno $^{23}$. El conde de Toreno, por ejemplo, un militar de la izquierda del liberalismo, consideraba que esta nueva fuerza iba a constituir un mecanismo clave en el sistema constitucional de contrapesos. Según él, la Milicia era un Ejército parlamentario orientado a mantener bajo control el poder del trono:

El ejército ha de atender principalmente á la defensa exterior del Estado, y las Milicias á conservar el órden interior, y mantener en toda su integridad la Constitucion siempre que se quisiese destruirla violentamente. El primero debe estar en consequencia á disposicion de la potestad ejecutiva [es decir, del Monarca], y las segundas en una absoluta independencia de ella [es decir, bajo el control del parlamento] ${ }^{24}$.

Toreno era igual de radical en su concepción de la organización interna de este cuerpo: se refirió a sus miembros como «ciudadanos», y subrayó así

21 Constitución española de 1812, título VIII, capítulo II, art. 362-365.

22 Ruiz de Morales (1855): 113f y $116 f$.

23 El siguiente párrafo debe mucho a Blanco Valdés (1988): 188-194. Además de la intervención de Toreno, es necesario mencionar a Argüelles (2011): 123f.

24 Diario de Sesiones de las Cortes Generales y Extraordinarias. Legislatura 1810-1813, 1870: 16-1-1812, 2633-2635. Cita: 2633. 
que, por primera vez en la historia de España, un servicio armado se basaba en la condición de la persona como un ser políticamente activo y miembro igualitario de una comunidad nacional ${ }^{25}$. Esta revalorización de los miembros de este cuerpo se reflejaba también en su demanda de que los oficiales fueran elegidos por los propios milicianos.

Como ya hemos señalado, los artículos constitucionales sobre la Milicia se quedaron cortos en relación con las esperanzas de Toreno y otros radicales. Sin embargo, otra característica de esta fase temprana consistió en que el debate en torno del armamento cívico y de las posibilidades que ofrecía de cara al control del Gobierno no se limitó a los estratos superiores de las élites políticas. Esto ha quedado ilustrado en los llamados Informes sobre Cortes.

Estos informes son una recopilación de documentos con propuestas para la nueva Constitución, que tanto individuos como colectivos (desde obispos y autoridades municipales hasta simples ciudadanos) dirigieron a la junta que estaba preparando las Cortes ${ }^{26}$. Demuestran, en primer lugar, que el pensamiento más radical de la Ilustración había alcanzado a sectores variados de la población. Un ciudadano particular de Galicia, por ejemplo, subrayaba la superioridad del sistema de milicia invocando los planteamientos ya mencionados de Rousseau sobre el armamento cívico ${ }^{27}$. En segundo lugar, estos documentos muestran que sus autores mezclaban un léxico tradicional y un enfoque territorializado con los nuevos valores ilustrados. Un ejemplo es la contribución del Ayuntamiento de Palma, en la que se combina conceptos tradicionales como "vecino" y «vasallo» con nociones nuevas de nacionalidad e igualdad: propone una versión reformada de las milicias provinciales que aúne "con masa" $\mathrm{y}$ "sin distinción de clases, de uniformes ni de insignia [...] todos los vecinos de cada provincia», puesto que la heroica resistencia de «la ilustre nación española» contra los franceses había demostrado que «la íntima unión de todos los vasallos es la verdadera fuerza $»^{28}$.

La contribución del Ayuntamiento de Cádiz también demuestra cómo esta mezcla de viejo y nuevo vocabulario puede entrelazarse con los sucesos políticos en curso y usarse para cuestionar el control del rey sobre las Fuerzas

Íd.

26 Estos informes pueden consultarse en el Archivo del Congreso de Diputados (ACD). Los procedentes de Baleares, Valencia, Aragón, Andalucía y Extremadura fueron editados por Federico Suárez (1967b). Las posturas adoptadas por estos en asuntos militares son debatidas por López Garrido (1982).

27 Véase la propuesta enviada por Panadero, ACD, Papeles reservados a Fernando VIII, 7-15.

28 Suárez (1967a): 219-221. 
Armadas. Tras su advertencia de que un monarca con poder absoluto sobre el Ejército podía abusar del mismo con gran facilidad, este Ayuntamiento preguntaba: «¿Quien ha dicho que el Soberano de España, según la Constitución, puede disponer del ejército a su placer y sólo por sí? $)^{29}$. Y tras recordar que las tradicionales Cortes representativas de los diferentes reinos de Espańa siempre poseyeron el derecho a formar sus propias Fuerzas Armadas y remarcando que esto había sido así desde la Reconquista, el texto planteaba otra pregunta:

Si cuando los Monarcas, con derramamiento de la sangre suya y de sus súbditos, ganaron y libraron esta tierra de los infieles moros y enemigos de nuestra Santa Fe Católica, no pudieron menos de esmerarse en conceder franquicias al pueblo español, ¿̨cuántas no deberá tener hoy, cuando él por sí mismo, sin Monarca, sin Grandeza, sin Nobles, ha defendido y rescatado con asombro del universo, su patria, su Rey, su Religión y su libertad?30

Por lo tanto, si por un lado el texto alude a antiguas libertades y privilegios propios de la Edad Moderna, por otro también introduce el principio de que la participación popular en la guerra contra Napoleón debería otorgar derechos a la población y/o a sus representantes. Varios artículos de periódico también mencionan la participación en la defensa del país como un medio para ganar derechos y dignidad: «¿La sangre de quinientas mil víctimas sacrificadas en aras de la amada patria no han [sic] bastado [...] a que se nos nombre con el honroso dictado de ciudadanos? »31.

Al mismo tiempo, la defensa aludida seńala hacia un tercer elemento que convierte esta fase temprana en un momento decisivo: la guerra de la Independencia había ya resucitado a los cuerpos locales de ciudadanos armados antes de que se promulgaran los artículos sobre la $\mathrm{Milicia}^{32}$. Su existencia igualmente contribuyó al uso y a la aplicación de nuevos principios y vocabularios políticos. Esto ha quedado patente en el ejemplo de la famosa milicia de Cádiz, que sus contemporáneos ya consideraban un posible modelo para la posterior Milicia Nacional ${ }^{33}$.

Suárez (1974): 170.

Ibid.: 171.

El Tribuno del Pueblo, 20-2-1814, citado en Peyrou (2004): 170.

32 Nos vamos a centrar exclusivamente en cuerpos armados estables y estrictamente locales, dejando a un lado las guerrillas, que difieren profundamente de la Milicia Nacional. Sobre su controvertido impacto, Esdaile (2004) y Fraser (2008).

33 La Abeja Española, 20-1-1813. Véase también la intervención de Canga Argüelles, reproducida en El Conciso, 27-3-1814. 
Cádiz poseía diversos cuerpos de defensa local no profesionales y organizados de una manera socialmente estratificada. El más famoso eran los Voluntarios Distinguidos, y estaba compuesto por los miembros más adinerados. Si bien el estudio de Esdaile ha deslustrado su prestigio, no es casualidad que su reglamento interno fuera considerado pionero en la materia ${ }^{34}$. No solo fue desarrollado por los propios miembros del cuerpo, sino que ponía en sus manos la responsabilidad administrativa del mismo. Pero lo que resulta aún más importante: la palabra «ciudadano» aparece repetidamente en el texto de este reglamento, frecuentemente vinculada con el concepto de igualdad (legal). Enfatiza, por ejemplo, que los voluntarios están «ligados entre sí por los vínculos de amistad, parentesco y conformidad de derechos en clase de ciudadanos $»^{35}$. Esta igualdad de sus miembros, como también aclara el reglamento, nunca debe infringirse por ninguna desigualdad que pueda regir la vida social fuera del cuerpo. El honor, por ejemplo, es definido como «virtudes patrióticas y sociales independientes de influxo, nacimiento ó riquezas ${ }^{36}$.

Si bien el carácter selecto de los Voluntarios Distinguidos arroja dudas sobre la sinceridad de estas declaraciones, la existencia de su reglamento fue importante para otras unidades: en por lo menos dos artículos periodísticos, un miembro de la artillería urbana recurre a la concepción del honor según dicho reglamento para argumentar contra la forma humillante con que los oficiales de su milicia tratan a la tropa ${ }^{37}$.

Si bien los cuerpos de ciudadanos armados de otras ciudades no recibieron tanta atención como la guardia de Cádiz, sus evoluciones también tuvieron un estrecho seguimiento, especialmente en Madrid. Durante los periodos en que la capital no se hallaba bajo dominio francés, sus periódicos

34 Para una mordaz crítica a los Voluntarios Distinguidos, Esdaile (2004): 75-77. Sobre las diferentes unidades de milicianos: Solís (2012): 164ff.

35 Reglamento del regimiento de Infanteria de linea de Voluntarios distinguidos de Cádiz, 1811, cap. XIX, art. 54, p. 106f. Es cierto que la expresión «en clase de ciudadanos» parece aludir a un estatus especifico que estos individuos disfrutaban dentro su comunidad local. No obstante, si bien el texto utiliza tanto el término "ciudadano» como el de "vecino», es la palabra "ciudadano» la que el texto vincula con igualdad y derechos. Sobre el término "ciudadano", Aranda Pérez y Sanz Camañes (2003). Sobre su oposición a «vecino», Cabrera (2014): $61 f$.

36 Reglamento del regimiento de Infanteria de linea de Voluntarios distinguidos de Cádiz, 1811, cap. 1 art. 3 corolario 3, p. 3.

37 El Conciso, 5-3-1812; El Redactor general, 4 de marzo de 1812. Solo El Redactor general publica el texto íntegro. 
anunciaron por lo menos cinco panfletos sobre la Milicia Nacional ${ }^{38}$. Algunos de estos documentos establecían una sólida conexión entre la Milicia y las autoridades locales o subrayaban que para servir como miliciano uno tenía que reunir cualidades que hasta entonces nunca se habían relacionado con los asuntos militares ${ }^{39}$.

El cuarto elemento que cabe mencionar sobre esta primera fase es que ya entonces las discusiones en torno a la Milicia Nacional constituían un punto de encuentro y conflicto entre los debates parlamentarios y la opinión pública. Esto resultó especialmente cierto tras el traslado de las Cortes a Madrid, en la primavera de 1814. Durante el debate sobre la ley de la Milicia, las galerías estaban colmadas de público. Este intervenía en las argumentaciones parlamentarias con gritos e insultos, tomando parte claramente por los radicales. La pregunta del diputado Gómez sobre quiénes eran los enemigos domésticos - es decir, enemigos del orden constitucional — a quienes se temía tanto que se necesitaban la Milicia, fue respondida por espectadores gritando «iÁ ti! ¡í ti!». La propuesta de Larrumbide de posponer el debate provocó gritos de “iMuérete! ¡Muérete!»" Algunos políticos de la izquierda, como Canga Argüelles, intentaban deliberadamente agitar al público gritando y gesticulando de forma expresiva ${ }^{41}$. El ambiente estaba tan caldeado que los periódicos se preguntaban si se seguía garantizando la libertad de expresión ${ }^{42}$.

Por lo tanto, ya en aquellos años tan tempranos diversos actores heterogéneos vinculaban a la guardia cívica con el deseo de controlar al Gobierno.

38 Dos de ellos se pueden consultar: Defectos cometidos en el arreglo de la Milicia Urbana de Madrid y Respuesta al pretendido reformador de la Milicia Urbana. Los títulos de los demás son: Defectos cometidos en el arreglo de Milicia urbana de Madrid; Segunda carta sobre los vicios en el arreglo de la Milicia urbana, y plan cómodo y facil de conseguir el objeto á consecuencia de la respuesta dada por D. Antonio Ruiz (1812); El amigo de la Milicia urbana nacional de Madrid; Por un patriota (1813), y Defectos cometidos en el arreglo de la Milicia urbana de Madrid y plan sencillo y económico de establecer en todo el reino sobre los principios de la constitución (1814).

39 Defectos cometidos en el Arreglo de la Milicia urbana de Madrid, 1812; Ruiz, (s. f.)

40 Diario de Mallorca, 29-4-1814; El Procurador general de la nación y del Rey, 28-31814.

41 Los periódicos aportan una viva descripción de este debate, solo parcialmente recogido en el Diario de Sesiones. El Procurador general de la nación y del Rey describe de forma más detallada este debate, en sus ediciones del 27 y 28 de marzo de 1814. El número del 27 de marzo ofrece una descripción del comportamiento de Canga Argüelles. Para más información sobre el debate y el ambiente que lo rodeaba, $E l$ Conciso, 27-3-1814.

42 El Procurador general de la nación y del Rey, 3-4-1814. 
Al mismo tiempo, las experiencias precursoras de la Milicia Nacional contri-

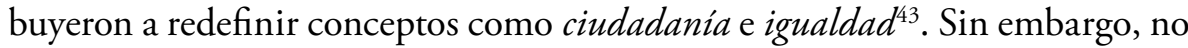
podemos saber qué otras dinámicas podrían haberse desarrollado a raíz de este debate sobre la Milicia, pues quedó truncado. El regreso de Fernando VII, en abril de 1814, abortó el experimento constitucional. No obstante, su posterior evolución durante el Trienio Liberal demuestra que las semillas plantadas en esta primera fase no se perdieron.

\section{LOS ALBORES DE LA MILICIA}

En la primavera de 1820, un pronunciamiento obligó a Fernando VII a restablecer la Constitución de Cádiz. Se inició así una segunda fase de gobierno constitucional en España, el llamado Trienio Liberal. Este periodo suele ser considerado el apogeo de la Milicia Nacional; no en vano, el 7 de julio de 1822 la guardia cívica derrotó un alzamiento realista ${ }^{44}$. Pero estos sucesos y los constantes conflictos entre realistas y constitucionalistas delatan las enormes tensiones que estaban marcando la vida política. A esto se sumó además una división creciente entre los propios liberales ${ }^{45}$. Las divergencias entre liberales moderados y radicales se reflejaron y exacerbaron precisamente por sus posicionamientos con respecto a la Milicia Nacional: mientras que los moderados adoptaron una actitud crecientemente escéptica, los exaltados planteaban una visión de la misma cada vez más radicalizada. Esa radicalización recogía la viva cultura política extraparlamentaria que se había ido desarrollando en el entorno de la Milicia Nacional.

Los siguientes párrafos describen primero la radicalización del debate parlamentario, luego reconstruyen la imagen de los milicianos en la cultura pública para terminar analizando las descripciones que estos realizan de sí mismos.

La legislación del Trienio Liberal sobre la Milicia Nacional vinculaba estrechamente el servicio miliciano con la ciudadanía: todas las leyes de este periodo estipulaban que solo los ciudadanos podían participar en este cuerpo. Y la ley de septiembre de 1822 incluso encomendó a la Milicia la protección de la Constitución, resaltando así su función política ${ }^{46}$. Pero los debates parlamentarios en

43 El ejemplo de la práctica peticionaria también muestra cómo se solapan viejas y nuevas prácticas durante esta primera fase de gobierno constitucional: Palacios Cerezales (2019).

44 Pérez Garzón (1975).

45 Una viva descripción del Trienio Liberal y sus culturas políticas, Comellas (1963).

46 Reglamento de 1822, art. 61. 
torno a esta ley demuestran hasta qué punto entre los propios liberales las visiones comenzaron a divergir: mientras que en 1820 los moderados apoyaron la ampliación del servicio, así como la desmilitarización de la Milicia, en vísperas del debate de 1822 proponían abolir las unidades de milicianos voluntarios - es decir, más activas-, una sugerencia que algunos interpretaron como un intento de desmantelar toda la Milicia Nacional ${ }^{47}$.

Los diputados exaltados, por su lado, hicieron alarde de sus planteamientos más radicales sobre la Milicia precisamente en este mismo debate de 1822. No contentos con la autonomía de los milicianos y con las tareas a ellos encomendadas, numerosos diputados de la izquierda reclamaron que la nueva ley les otorgara el derecho a la resistencia ${ }^{48}$. En especial, las intervenciones de Antonio Alcalá Galiano muestran que seguía viva la concepción de Toreno de la Milicia Nacional como parte de un sistema de contrapesos políticos, incluso plateándola en términos más agresivos. Alcalá Galiano concebía este equilibrio de poderes como una genuina hostilidad entre las diferentes instituciones constitucionales y por ello defendía que la Milicia quedara siempre bajo el control de autoridades elegidas, locales y civiles ${ }^{49}$.

Aunque los políticos más izquierdistas demostraban su creciente confianza en la ciudadanía, en las intervenciones de los diputados la necesidad de la Milicia seguía derivando principalmente de la teoría constitucional. El papel de la ciudadanía seguía pensándose de modo abstracto. No obstante, la recuperación del gobierno constitucional reverberó en la vida pública, donde se desarrolló un verdadero culto a los milicianos. Como en la fase anterior, uno de los valores centrales asociados a la Milicia era el de la igualdad ciudadana, percibida como clave para la integración social y nacional. La Gaceta de Gobierno, por ejemplo, anunciaba con no poco orgullo que en Málaga «el ayuntamiento ha repartido entre todas las compañías á los llamados gitanos, á quienes han recibido los demas con los brazos abiertos abatiendo asi ese muro de division entre ciudadanos y ciudadanos $\$$.

Pero al mismo tiempo, antes incluso de que fuera promulgada la ley sobre la Milicia Nacional de 1822, la cultura política extraparlamentaria ya otorgaba una función política específica a esta guardia cívica. Ya en 1820, una sociedad patriótica mallorquina aclaraba que consideraba el servicio en la Milicia como

47 El Zurriago, no. 39 (1822). Sobre el debate parlamentario, véase de nuevo: Blanco Valdés (1988).

48 Véase el artículo 185 del borrador de la ley presentado por la Comisión de Milicia: Diario de Sesiones de Cortes (DSC). Legislatura de 1822, 1872, 9-6-1822, $1792 \mathrm{ff}$.

49 DSC. Legislatura de 1822, 1872, 23-6-1822, 2104.

50 El Constitucional, 26-8-1820. 
un acto personal de participación en el poder político y lo describía como «uno de los actos mas esenciales de la soberanía». Incluso retrataba a los ciudadanos como los mejores guías de cualquier Gobierno y a la milicia como la expresión más manifiesta de ello: "Prevengamos pues tamańos males [por parte de gobierno], alistémonos en las milicias nacionales y digamos al mundo entero, creamos un Gobierno, le señalamos la ruta de nuestra Felicidad y armados y reunidos juramos sostenerle hasta el ultimo aliento." .

En la misma línea, el periódico Abeja del Turia declaraba en 1820: «La ley se impone por el que tiene la fuerza á su disposición [...]. [...] Desarmar el pueblo: esta ha sido siempre la primera maniobra de la táctica de los tiranos. [...] Si el pueblo jamás debe desprenderse de las atribuciones de legislador, tampoco deberá desprenderse de la facultad de defender sus leyes por sí mismo" y subrayaba así que la capacidad de defender la ley incluso la fuerza armada resultaba tan básico como legislar. Sin embargo, según este artículo, a diferencia del poder legislativo, el poder de defender las leyes no podía delegarse $^{52}$. Por lo tanto, la Milicia simbolizaba el vínculo entre el pueblo y el Gobierno. Este último, al tiempo, debía ser sometido a una constante vigilancia, labor para la cual la Milicia era vista como el instrumento más apropiado.

Como acabamos de ver en el rechazo a que el servicio en la Milicia pudiera delegarse, la posición prominente otorgada a esta iba de la mano de una sólida concepción de la responsabilidad ciudadana: según el periódico $E l$ Constitucional, todo ciudadano que pagara a otros para que protegieran su libertad no se la merecía ${ }^{53}$. En consonancia, algunos escritores desplegaron una viva imaginería en torno de unos milicianos modélicos. Pero como se muestra en dos obras de teatro, Una noche de alarma en Madrid, de Gorostiza, y El triunfo de la constitución, de Martí, la figura del miliciano no se limitaba a la de un apasionado defensor de la Constitución. Estas obras también lo representaban como a alguien que contribuía a una transformación profunda de la sociedad ${ }^{54}$.

51 Correo constitucional de Mallorca, 31-5 y 1-6-1820, citado en: Gil Novales (1975): 299. Cursiva en el original, también citado en: Blanco Valdés (1988): 414.

52 La Abeja del Turia, 2-5-1820. Cursiva en el original.

53 El Constitucional, 26-8-1820.

54 Una noche de alarma en Madrid constituyó la pieza central de una función teatral patriótica celebrada para recaudar fondos para las víctimas del terror antiliberal y fue considerada como una representación perfecta de las virtudes de los milicianos, $E l$ Universal, 25-6-1822. Se estrenó por primera vez el 12 de febrero de 1821, en una velada patriótica para conmemorar la bendición de la bandera de la caballería 
Aunque sus títulos aluden a refriegas en la calle, las dos obras no se centran en lucha armada en sí, sino en las trifulcas familiares que la preceden. Ambas obras inciden en los contrastes entre parejas compuestas por jóvenes milicianos y sus prometidas, con una pareja aristocrática de avanzada edad en un caso, y con un familiar conservador y también de mayor edad de una pequeña ciudad, en la otra obra. En comparación con estos familiares, los milicianos y sus prometidas no solo se distinguen por sus convicciones políticas, sino también por sus modos más naturales e informales de relacionarse; de hecho, todas las muchachas liberales que aparecen desempeñan papeles sorprendentemente activos. En El Triunfo..., antes de la lucha en las calles, las mujeres cantan himnos patrióticos y comparten un brindis con los milicianos, reforzando su confianza en la victoria. En Una noche de alarma... también la prometida del miliciano sigue al mozo cuando parte a la lucha. Al final, el liberalismo sale victorioso. Y no solo en el campo de batalla, sino también ideológicamente con la conversión al constitucionalismo de algunos realistas.

Pero estas obras no solo mostraban que el liberalismo era el futuro; también subrayaban su moderación. El cambio en los roles de género, por ejemplo, nunca excedía ciertos límites: las mujeres nunca llegaban a participar directamente en la pelea. En El Triunfo... el miliciano incluso llega a enfatizar la consonancia de la Constitución con los principios del catolicismo. De ahí el aire enormemente positivo que caracteriza a las obras y el doble mensaje que transmiten: el triunfo del liberalismo resulta inevitable, siempre que sea apoyado, en público y en privado, por una ciudadanía militante pero razonable, como la representada por los milicianos (y, en menor medida, por sus prometidas). Para apoyar este mensaje, ambas obras conectaban la movilización de los guardias con una puesta en escena de sus uniformes. Esto añade cierto aspecto cómico a la representación, pero también subraya el prestigio que otorga el uniforme. Su carácter abstracto recuerda también que cualquier ciudadano puede desempeñar el papel de miliciano, del cual, por otro lado, se espera una demostración pública y visible de su adhesión a los principios liberales.

También muchos periódicos invitaban a identificarse con la Milicia y con la ciudadanía comprometida al reproducir anécdotas de esposas que llevaban a sus maridos sus cartuchos y que les recordaban que debían priorizar

miliciana, y permaneció en cartelera aproximadamente una semana, siendo reestrenada en febrero de 1836: Diario de Avisos de Madrid, 2-2-1836; El Universal, del 13 hasta 18-2-1821. El triunfo de la constitución fue representada entre el 24 de diciembre de 1822 y el 2 de enero de 1823, Fernández Cabezón (2007): 65f; Freire López (2008): 76 . 
la patria sobre la familia ${ }^{55}$. Se dirigieron mensajes similares incluso a los miembros más jóvenes de la sociedad: en Sevilla los milicianos proyectaron un batallón juvenil con el fin de fomentar el espíritu constitucional, y en Barcelona un desfile de jóvenes voluntarios emocionó a los espectadores e inspiró al poeta Moratín a componer un poema patriótico ${ }^{56}$. En determinados grupos sociales vestir a los niños de milicianos pasó a formar parte de la etiqueta festiva, como por ejemplo en la familia del escultor Ponciano Ponzano. En sus memorias recuerda que expresiones de camaradería entre ciudadanos iguales, como el uso de nombre propio para dirigirse a los demás, entraron también en el seno de la vida familiar, resaltando así el papel de la Milicia como precursora del cambio social y su atractivo para aquellos que veían con buenos ojos estos cambios en la vida privada (como se sugerían las obras teatrales comentadas) ${ }^{57}$.

Que la seducción de la Milicia Nacional procediera precisamente de la visible identificación ofrecida por sus uniformes, como sugieren las citadas obras teatrales y el ejemplo de vestir de milicianos a los nińos, queda asimismo recogido en la propuesta de ley sobre la Milicia presentada por el Gobierno moderado en la primavera de 1822. La introducción del borrador de la ley criticaba a los jóvenes políticamente radicalizados por su exagerada costumbre de vestir el uniforme en toda ocasión ${ }^{58}$. Pero la crítica del Gobierno fue incluso más allá: presentaba a los voluntarios como alborotadores que propagaban la discordia incluso en los pueblos más pequeños y criticaba «los medios poco conciliadores que generalmente se han empleado para manifestar la adhesion á las instituciones liberales»" ${ }^{9}$. A este comportamiento turbulento, el Gobierno opuso el «carácter sesudo y circunspecto» propio de las gentes de provincias y el carácter supuestamente «dócil» del pueblo español. Aquellas zonas donde se daba una adhesión masiva a la Milicia, en cambio, fueron descalificadas como regiones donde «el genio y el carácter nacional están desfigurados». Ese borrador, a diferencia de las obras teatrales comentadas, no describía pues a los milicianos como ciudadanos modélicos y razonables, sino como la encarnación de una forma demasiado militante de hacer política.

55 El Universal, 28-11-1820.

56 Archivo municipal de Sevilla Secc. IX, Tomo 22 Doc. 9. La carta de Moratín del 11-071821 en Andioc (1973): 444-446n.

57 Véase el texto autobiográfico de Ponciano Ponzano publicado en Pardo Canalís (1951): 314ff.

58 Proyecto de Reglamento de Milicia Nacional Local Presentado a las Cortes por el Gobierno el 23 de Marzo de 1822

59 Todas las citas: ibid.: 3. 
Otras publicaciones, en su concepción de los milicianos y de sus deberes, rompieron de forma incluso más explícita que las obras de teatro descritas con el ideal de una población obediente. A partir de 1822, numerosas publicaciones anuncian la hostilidad que marcó la intervención parlamentaria de Alcalá Galiano, expresando una radical desconfianza hacia el poder gubernamental. Para hacerlo, recurrían a un tono conminatorio y emotivo: el Mensagero de Sevilla, por ejemplo, recordaba a los milicianos que habían sido armados para que "castigueis á los enemigos de nuestras instituciones [...] en el caso de que hicieran alguna tentativa contra vuestros sagrados derechos y deberes». Un par de meses después, el periódico madrileño El Zurriago justificaba el derecho de los milicianos a llevarse el fusil a casa basándose en la incapacidad y falta de voluntad gubernamental de actuar contra «los infames sectarios del gobierno despótico» ${ }^{60}$. Por lo tanto, el discurso público comenzó a transformar a la Milicia en un instrumento de justicia popular al que la población tenía el deber de recurrir.

Estas visiones de los milicianos no eran solo proyecciones externas. Esto queda bien ilustrado en cartas de milicianos de toda Espańa dirigidas a las Cortes para protestar contra la nueva ley de Milicia propuesta en la primavera de 1822. Como ya se ha mencionado, esta propuesta pretendió abolir la distinción entre las unidades de voluntarios y las compuestas por reclutas obligados por la ley. Intentó también limitar la capacidad de la tropa de elegir a sus oficiales y, en tercer lugar, quiso obligar a los milicianos a que dejaran sus rifles en depósito al terminar su servicio. Dichas cartas de protesta ejemplifican que los milicianos se consideraban a sí mismos "atalayas de vigilancia» del Gobierno. Es más, expresaban la pertenencia a una élite comprometida y reclamaban que las prácticas de las Milicias reflejaran y fomentaran semejante espíritu.

La Milicia de San Fernando, por ejemplo, calificó esta propuesta de ley como "criminal», pues en caso de no poder elegir a los oficiales se perdería la confianza entre los milicianos y «faltaria con ella la fuerza moral». Además, en vez de obligarlos a dejar sus armas en el depósito, lo obligatorio debería ser que no se separaran nunca de ellas: «Todos apeteciamos que el sistema [constitucional] estuviese tan consolidado que pudiesemos abandonarlas con seguridad, mas mientras llega tan suspirada epoca, parece seria mas conveniente obligar à todo miliciano que no las desamparase». Los guardias de Alcázar de San Juan y de Valencia incluso atacaron directamente al Gobierno: los primeros afirmaban que, con esta ley, el Gobierno estaba mostrándose «siempre ansioso de reducir por todos medios los derechos del ciudadano»;

60 El Zurriago, n. 39 (1822); Mensagero de Sevilla,10-1-1822. 
mientras que los milicianos de Valencia aseguraban que la Constitución solo podría mantenerse mientras las normas de la Milicia «sean enteramente liberales, y los Gefes que la manden sean verdaderos constitucionales-exaltados: de otra manera [...] lleguemos á ser victimas del Gobierno» ${ }^{61}$.

Se conoce muy poco sobre el contexto de estas peticiones. No obstante, como las cartas llegaron de diversas regiones, parece cuestionable que fueran el producto de una campaña "perfectamente preparada» por el partido exaltado, como sugiere Blanco Valdés ${ }^{62}$. Merece pues considerar que la movilización contra la ley se produjo no tanto porque el ala exaltada controlara a la Milicia, sino porque al abogar por una mayor independencia de la misma los exaltados adoptaron y promovieron un modelo de ciudadanía que los propios milicianos consideraban atractivo y con el que se identificaban. Resulta además llamativo hallar autodescripciones similares a las de estas cartas en contextos anteriores y diversos. Una carta de milicianos de Sevilla pidiendo a las Cortes que establecieran una unidad de artillería puede servirnos de ejemplo. Se trata de una misiva especialmente interesante, pues sus autores expresan una gran desconfianza hacia el Gobierno en general (es decir, no solo hacia el Gobierno moderado):

Todo poder ejecutivo, sea cual fuere su índole, tiende naturalmente a ensanchar el circulo de sus atribuciones y tarde o temprano hace presa de las libertades del pueblo, si este no presenta una fuerza respetable capaz de enfrenar las ambiciones de los que gobiernan. [...] Y que institución mas adecuada que la Milicia local voluntaria para [...] hacer respetar los derechos del Pueblo Soberano al déspota que fuera osado a hollarlos [...]?63

Esta petición demuestra una vez más que durante el Trienio Liberal el estrecho vínculo entre la Milicia y el control del Gobierno no se basaba únicamente en la teoría constitucional. Al menos, algunos milicianos hicieron suyas estas ideas con el fin de definir su posicionamiento y justificar sus demandas. Entre 1820 y 1823 fueron sobre todo los moderados quienes se sintieron desafiados por esa forma de hacer política. Sin embargo, en el lenguaje asociado a la Milicia la desconfianza política era ambigua y podía potencialmente dirigirse contra cualquier forma de autoridad. Finalmente, no hay que pasar por

61 Las cartas en $A C D, \mathrm{H} 3-\mathrm{T} 56$. Fueron enviadas a las Cortes por milicianos desde sus respectivos pueblos o ciudades y están fechadas entre el 30-4-1822 y el 17-5-1822.

62 Blanco Valdés (1988): 448-450. Cita: 449.

63 Archivo Municipal de Sevilla, Sec: IX, Tomo XXII, doc. 17; milicianos nacionales de la ciudad en una carta a las Cortes, marzo de 1822. 
alto que este tipo de comportamientos militantes y rebeldes no estaban necesariamente vinculados con las clases más bajas: como ya hemos visto, el borrador de ley de Milicia presentado por el Gobierno en 1822 criticaba específicamente el comportamiento de personas suficientemente adineradas como para costearse un uniforme.

Los sucesos que pusieron punto final al Trienio Liberal demuestran que la desconfianza de la ciudadanía hacia el poder ejecutivo no estaba injustificada: en 1823, Fernando VII volvió a maniobrar exitosamente para restablecer el régimen absolutista. Como en 1814, la Milicia desapareció junto con la Constitución. En cambio, en la siguiente década se organizó un cuerpo paramilitar fiel al Gobierno absolutista: los Voluntarios Realistas. Si bien este cuerpo, a diferencia de la Milicia Nacional, no se basaba en conceptos como la ciudadanía, sino en la obediencia, en la fe y también, por lo menos en parte, en la paga, fue no obstante representado como una especie de contramilicia. Mantuvo esa fama incluso tras la muerte de Fernando VII, cuando bajo la regencia de su esposa María Cristina se puso en marcha un gradual regreso al constitucionalismo ${ }^{64}$.

\section{LOS PRIMEROS AÑOS DEL REINADO DE ISABEL ॥}

En la historia institucional de la Milicia, los años de la regencia de María Cristina resultan ciertamente los más difíciles de analizar. Las leyes, decretos e incluso los nombres de esta fuerza sufrieron rápidos cambios y la primera guerra carlista desencadenó la formación de unidades militares movilizadas y pagadas al margen de la Milicia ${ }^{65}$. Al mismo tiempo, desde el principio se encendieron conflictos sobre quién podía formar parte de la guardia cívica, lo que caldeó tanto los debates a pie de calle como los parlamentarios. Como se verá en el siguiente apartado, las dos corrientes políticas predominantes en el liberalismo espańol por entonces, los moderados y los progresistas, reaccionaron de forma diferente a estas dinámicas.

Numerosos pequeños conflictos locales acompañaron la reimplantación de la guardia cívica desde mediados de la década de 1830 en adelante. Estos conflictos y los informes al respecto demuestran que muchos miembros de la restablecida Milicia siguieron sintiéndose parte de una vanguardia política

64 Subsiste cierto desacuerdo sobre si estos Voluntarios Realistas recibían paga. Véase: París Martín (2015): 59f y Rújula López (1998): 94-124, esp. 119.

65 Santirso Rodríguez (1995). Sobre los batallones móviles: Herrero Maté (2003): 167f y Portet i Pujol (2003): 140-143. 
liberal. Cuando en Sevilla un escribano de la Real Audiencia, «marcado por sus opiniones contrarias al gobierno», apareció vistiendo el uniforme de la milicia, unos guardias intentaron quitárselo públicamente ${ }^{66}$. En Valencia, un guardia recordó a un ex-Voluntario Realista que no tenía legitimidad para corear con ellos canciones a favor de Isabel $\mathrm{II}^{67}$.

Las publicaciones oficiales hacen también referencias a problemas semejantes. Una circular de la Comandancia Militar Provincial dirigida a los comandantes generales de Castilla la Nueva recuerda que solo porque las nuevas leyes hayan otorgado a los milicianos una tarea importante «no [...] se les constituye en jueces ni en fiscales de las acciones de sus convecinos [...]. El imperio de la ley no se sostiene con gritos ni con la exaltación de ideas y de cosas impracticables ${ }^{68}$. Por tanto, parece que numerosos milicianos reclamaban el papel de guardianes del liberalismo que la cultura política del Trienio Liberal les había otorgado. Al tiempo, estos ejemplos muestran que la concepción de los milicianos como ciudadanos vigilantes había experimentado un giro muy concreto: dicha vigilancia ya no se limitaba al Gobierno — tal vez ya no fuera ni siquiera su función primaria—, sino que afectaba también a los demás ciudadanos.

Moderados y progresistas poseían diferentes respuestas para una pregunta con una carga emocional tan explosiva como quiénes debían ser miembros de la guardia cívica. Esto se hizo patente en el debate parlamentario sobre el servicio miliciano obligatorio en otońo de 1834 . Por un lado, los parlamentarios eran bien conscientes de que el acceso a la Milicia tenía un impacto sustancial en la actitud de la población hacia el sistema político. El diputado moderado Somuruelos, por ejemplo, señaló que la hostilidad contra el sistema constitucional no constituía un hecho en sí, sino que era más bien producto precisamente de las exclusiones de la propia guardia cívica. Según él, un servicio de milicia obligatorio para todos los hombres, independientemente de sus opiniones políticas, era un instrumento necesario si se quería evitar una exacerbación de los conflictos políticos en curso $^{69}$.

Fue especialmente el primer ministro moderado Martínez de la Rosa quien destacó el poder transformador de una Milicia ideológicamente neutra: según él, el proyecto de ley del Gobierno sobre la guardia cívica «evita darle

66 Diario Balear, 2-6-1834.

67 «Acontecimientos de la puerta del mar» en el Archivo Municipal de Valencia, Sección de la Milicia, c.49

68 La Abeja española, 15-11-1833.

69 Intervención de Somuruelos: Diario de Sesiones de Cortes. Estamento de Procuradores. (DSC-EP), Legislatura de 1834 á 1835, vol I, 13-11-1834, 708. 
ningun color de partido político; y antes bien quiere que se dirija á un objeto común: la defensa de los propios hogares, de la pública tranquilidad, de las leyes ${ }^{70}$. Así, a sus ojos el servicio miliciano derivaba de intereses sociales comunes, por lo que constituía una oportunidad para aproximar diferentes posturas políticas.

Diputados radicales como Joaquín María López, Antonio Alcalá Galiano y el conde de las Navas, por su lado, lo veían de otra manera. Se oponían fuertemente a una Milicia políticamente inclusiva, en la medida en que pensaban que las diferencias políticas no podían ni debían ser superadas. Defendían que el servicio fuera voluntario, con la esperanza de que solo atrajera a liberales convencidos. Así que cuando el Parlamento optó por un servicio obligatorio, los diputados radicales lucharon por introducir un párrafo que permitiera exclusiones por razones políticas ${ }^{71}$. Las intervenciones de Alcalá Galiano demuestran claramente los nuevos ímpetus que estaba alcanzando el debate. Así que, en vez de pretender mitigar las pasiones que el servicio miliciano desencadenaba, Alcalá Galiano defendía que, dada la situación del momento, había incluso que aprovecharlas.

En sus discursos Alcalá Galiano dejó claro que para él España se hallaba en una revolución debido a la guerra carlista. Se oponía así al tipo de reconciliación a la que aspiraba el Gobierno con su proyecto sobre la Milicia: «Todo esto lo anuncio, porque de aquí parto para oponerme à la aprobación de ese proyecto, á la idea de esa fusion completa de partidos, de esa reconciliación de amigos y enemigos que se proponen hacer los Sres. Secretarios del Despacho $»^{72}$. Es más, Alcalá Galiano enfatizó que semejante guerra de principios políticos no podía ser ganada dirigiéndose a las dimensiones materiales o racionales de los individuos (como parecía implícito en la justificación de Martínez de la Rosa de su proyecto de milicia), sino solo a las emocionales. Y a su parecer, una de las principales herramientas para suscitar dichas emociones era el servicio voluntario en la Milicia ${ }^{73}$.

Alcalá Galiano no se hallaba solo en su idea de que la dimensión emocional del servicio miliciano debía ser alentada con el fin de beneficiar a la causa del liberalismo radical. El diputado Ferrer, por ejemplo, propuso el uso de símbolos y rituales políticos para reforzar el vínculo sentimental entre los milicianos y el liberalismo, tal como hizo el himno de La Marsellesa en

\footnotetext{
DSC-EP 1834 á 1835, vol. I, 13-11-1834, 712.

Entre otros, DSC-EP 1834 á 1835, vol. II, 18-11-1834, 738.

DSC-EP 1834 á 1835, vol. I, 12-11-1834, 702.

73 Íd. Sobre el entusiasmo, véase también la intervención de Istúriz el 13-11-1834.

DSC-EP 1834 á 1835, vol. I, 711.
} 
Francia $^{74}$. Pero fueron especialmente las intervenciones de Alcalá Galiano las que demuestran una concepción instrumental de la guardia cívica y de las emociones a ella asociadas. Refiriéndose a las preocupaciones expresadas por otros diputados sobre las actuaciones de milicianos excesivamente exaltados, Alcalá Galiano mantuvo que «así como un barco necesita de un viento fuerte para salir de ciertas situaciones apuradas así nosotros nos debemos aprovechar de esas pasiones fuertes que bien manejadas, no son peligrosas como se supones 75 .

Puesto que no fueron capaces de imponerse en el Parlamento, los políticos radicales intentaron poner en práctica su idea de fomentar las pasiones de los milicianos con el fin de aprovecharlas en sus propias luchas de poder. Con la primera guerra carlista en curso y un predominio de los moderados en el Parlamento nacional, varios progresistas no solo contactaron con milicianos madrileńos para que, en el verano de 1835, presionaran al Gobierno moderado para que acometiera reformas constitucionales ${ }^{76}$, sino que también intentaron instigar maniobras similares en los centros regionales. López, por ejemplo, viajó a Valencia, donde contactó con una junta miliciana revolucionaria, publicó artículos incendiarios e incluso promovió un sentimiento antimadrileño ${ }^{77}$. El conde de las Navas, por su lado, encabezó una columna armada que se dirigió de Andalucía hacia Madrid ${ }^{78}$.

Y sus planes tuvieron éxito. En 1835, insurrecciones municipales respaldadas por milicianos llevaron al poder a un Gobierno dirigido por los progresistas. Sin embargo, puesto que los conflictos internos entre liberales seguían abiertos, las facciones más radicales intentaron repetidamente aprovechar las rebeliones regionales que asolaban el país; no menos hizo Espartero, quien desde finales de la década de 1830 era el general progresista en ascenso ${ }^{79}$. Basándose en las juntas revolucionarias de las ciudades y abogando por una mayor autonomía urbana, a comienzos de la década de 1840 Espartero logró consolidar su poder y el de su partido. En otoño de 1840, este general escenificó entradas triunfales en Barcelona y Valencia, durante las cuales milicianos se uncieron a su carruaje para pasearlo por las calles ${ }^{80}$. Fueron precisamente estas actuaciones, y los panfletos que las acompañaban, las que desde finales

\footnotetext{
DSC-EP 1834 á 1835, vol. III, 10-3-1834, 1817.

DSC-EP 1834 á 1835, vol. I, 12-11-1834, 702. Las cursivas son mías (LZ).

Caballero (1857): 73-78.

Burdiel (1987): 171ff y Caballero (1857): 73-78.

Una reunión de amigos Colaboradores (1845).

Sobre los alzamientos regionalistas: Moliner i Prada, (1997).

80 Fuentes (2007): 137.
} 
de la década de 1830 en adelante escenificaron una relación supuestamente armoniosa entre la Milicia Nacional y los progresistas ${ }^{81}$.

No obstante, al aliarse tan estrechamente con milicias locales insurreccionales, los progresistas también contribuyeron a reavivar los aspectos más localistas del discurso político, tradicionalmente asociados al armamento urbano, como se relata en el Informe sobre Cortes del Ayuntamiento de Cádiz. El ejemplo de Barcelona delata que estas derivas localistas no habían sido olvidadas. Las repetidas insurrecciones en la capital catalana condujeron a una lucha permanente relacionada con la existencia y la organización de la Milicia entre las autoridades locales y su población, por un lado, y el gobernador militar nombrado por el Gobierno central, por el otro. Relatos sobre estos conflictos muestran, en primer lugar, la relevancia que tenía la Milicia para el sentimiento de pertenencia nacional. Ante la disolución en 1837 de varias unidades, los milicianos declararon que se sentían amputados y abandonados por el resto del país ${ }^{82}$. Pero estas protestas contra la disolución también contenían referencias explícitamente localistas: los milicianos aprovecharon la deposición de los pendones de las unidades disueltas para comparar los conflictos del momento con la Guerra de Sucesión (1701-1714), que había resultado en la disolución de la antigua Milicia Urbana de Barcelona ${ }^{83}$.

Para cuando, en 1841, incluso los progresistas liderados por Espartero intentaron retomar el control gubernamental sobre la rebelde ciudad y exigieron la disolución de las juntas, los elementos regionalistas seguían cobrando fuerza. Así, por ejemplo, los ciudadanos de Barcelona destruyeron la fortaleza que dominaba la ciudad. En el Manifiesto de la Milicia Nacional Armada, declararon que mientras siguiera existiendo esa fortaleza la tiranía persistiría, que la habían asaltado porque el territorio pertenecía a los ciudadanos, no a la nación, "porque somos libres, porque somos Catalanes» ${ }^{84}$. Es más, el deán de la Junta de Vigilancia, Llinas — ya miembro de la Milicia durante el Trienio Liberal-, recordó a sus compañeros que «este triunfo es una verdadera conquista. Victoria, pues, por Cataluña, victoria por los Catalanes, victoria por Barcelona ${ }^{85}$. Y al hacerlo, mostró a los sublevados la insignia de la Milicia Nacional subrayando que no solo había resultado crucial

81 Ejemplos de obras teatrales que muestran a los milicianos como fieles aliados de Espartero en De la Fuente Monge (2013).

82 A las Córtes, parece que Barcelona está segregada del resto de la Monarquía (1837).

83 Al Publico, las insignias de los antiguos cuerpos de Milicia Nacional van a ser depositadas (1840)

84 Manifiesto de la Milicia nacional armada de Barcelona (1841): 12.

85 Llinas (1841). 
para la toma victoriosa de la fortaleza, sino que también encarnaba a una Barcelona y a una Cataluña libres.

Por tanto, de forma similar a lo propuesto por los progresistas en el Parlamento, los revolucionarios de Barcelona recurrieron a las pasiones evocadas con los símbolos de la Milicia. Sin embargo, al recurrir a la heterogénea herencia de los cuerpos civiles armados, los revolucionarios enlazaron la Milicia no solo con ideas políticas radicales, sino también con planteamientos localistas. Haciendo esto, le dieron la vuelta a su contenido simbólico contra los intereses de los propios líderes progresistas.

Debido al posterior bombardeo de la ciudad, los sucesos de Barcelona de 1841 tuvieron un especial efecto dramático. Sin embargo, las insurrecciones urbanas protagonizadas por la Milicia no fueron fenómenos puntuales ni aislados, ni siquiera cuando el Gobierno estaba bajo mando progresista ${ }^{86}$. Por eso, a mediados de la década de 1840 no fueron solo los moderados de viejo cuño los que acusaron a la guardia de haberse convertido en el baluarte de una democracia descentralizada. Fue precisamente un antiguo progresista como Antonio Alcalá Galiano quien, en sus Lecciones de derecho constitucional, desarrolló una de las críticas más exhaustivas de la Milicia.

Alcalá Galiano comenzaba aclarando que esta guardia era un invento específicamente contemporáneo. Deslegitimaba así toda vinculación con las antiguas milicias urbanas de la Edad Moderna, y por ende con los privilegios municipales de aquella misma época, como se sugería en los panfletos publicados durante las insurrecciones de Barcelona ${ }^{87}$. En segundo lugar, cuando Alcalá Galiano aludía al revuelo provocado por una obra teatral de Bretón de los Herreros crítica con la Milicia, abordó - y en esta ocasión, con tono muy crítico- las pasiones que podía provocar una fuerte identificación con la misma $^{88}$. Pero lo que es más importante, en tercer lugar Alcalá Galiano insistía en que se daba una contradicción básica entre la vida moderna y el servicio en la guardia cívica: "Deben desaparecer [las milicias] [...] poniendo término final á su existencia por ser esta incompatible con un estado cual le han menester las sociedades presentes, no ya como las repúblicas antiguas dadas sobre todo á la guerra, sino cultivadores de las artes, de la paz, bajo una religión santa, y con costumbres blandas y suaves» ${ }^{89}$.

Esta cita no solo alude a la distinción de Constant entre la libertad de los antiguos y la de los modernos: Alcalá Galiano incluso cita a Constant en un

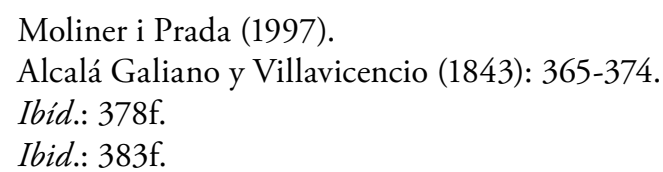


texto previo y acepta su diferenciación entre la libertad moderna, centrada en la protección del individuo y de la propiedad, y la libertad antigua, basada en la participación. Todo sugiere que la petición de Alcalá Galiano de abolir la Milicia formaba parte integral de un rechazo más amplio a un modelo de ciudadanía que anteponía el empeño cívico. Sus tratados parecen indicar que ya a comienzos de la década de 1840 incluso sectores progresistas de los liberales comenzaron a rechazar a la Milicia Nacional, no solo por las dificultades prácticas que suponía su organización, sino porque las ideas de participación política que evocaba y las fuertes identificaciones que generaba ponían en cuestión todo orden político centralizado y jerárquico.

\section{CONCLUSIÓN}

Ya desde su inicio, los debates en torno a la Milicia Nacional desempeñaron un papel central en la redefinición de las ideas de participación política. Resultaron especialmente eficaces en esta tarea porque podían vincularse con las críticas a la antigua organización militar. Se trató de un debate crucial porque, en su contexto, los discursos parlamentarios y extraparlamentarios se solapaban e influían mutuamente. Al abordar el Trienio Liberal este artículo ha hecho hincapié en modelos e ideales relacionados con la Milicia y la autoconfianza de sus miembros. Después, en los inicios del reinado de Isabel II algunos diputados realzaron los aspectos más emocionales de la guardia cívica, ya presentes desde hacía tiempo en la cultura política extraparlamentaria, y abogaron por aprovecharlos. Sin embargo, en su pretensión de usar a su favor dicha dimensión emocional, estos diputados también despojaban a la Milicia de sus elementos más emancipadores, aspirando así a convertirla en un instrumento de partido. Pero como ejemplifica el caso de Barcelona, no era fácil lograrlo.

Muchos de estos resultados requieren aún una mayor profundización y matización, especialmente mediante análisis sociales minuciosos que presten también una mayor atención a cómo influyó la Milicia en la construcción de categorías sociales como la clase, el género, la nacionalidad y tal vez incluso la etnia ${ }^{90}$. No obstante, a estas alturas del análisis ya se pueden obtener algunas claves generales. Por un lado, debido a su fuerte énfasis en el compromiso ciudadano y en la desconfianza hacia las autoridades, el ideal del miliciano

90 Si bien la cuestión de la etnia parece menos relevante en España que en las Américas, la incorporación de gitanos a la Milicia nos sugiere que este aspecto merece mayores indagaciones. 
nacional contiene numerosas similitudes con la imagen del ciudadano vigilante, que los primeros discursos liberales representaban como una atalaya que controlaba a los gobernantes. En especial, la evolución de la Milicia durante el Trienio Liberal sugiere que los milicianos se identificaban con este ideal, considerando a este cuerpo armado civil como el lugar donde encarnarlo. En cuanto a fases posteriores, hay datos que también sugieren que esta vigilancia ciudadana seguía resultando atractiva y vinculada a la guardia cívica. Por tanto, el creciente cuestionamiento de la Milicia Nacional también puede ser entendido como parte integral de un cuestionamiento cada vez mayor de este modelo de activismo ciudadano, implícito en la crítica hacia la Milicia de Antonio Alcalá Galiano en la década de 1840.

Por otro lado, este artículo ha señalado la polifonía de los discursos relacionados con la Milicia. Ha mostrado que diversos individuos y actores locales sabían cómo usar sus variados aspectos con el fin de justificar sus exigencias y actuaciones (que, cabe señalar, no tenían necesariamente por qué corresponderse con los intereses de los líderes nacionales del radicalismo). Todo esto implica que la Milicia Nacional acabó representando un problema para las élites políticas, no solo porque las clases más bajas también se integraron en ella, sino también porque los discursos políticos conectaban a la Milicia con conceptos de participación popular que amenazaban con minar unos liderazgos rígidos y altamente centralizados. Todo esto sugiere que la Milicia Nacional fue un laboratorio independiente de ciudadanía, y no un simple brazo armado de cualquiera de los partidos radicales emergentes.

\section{Bibliografía}

Alcalá Galiano, A. y Villavicencio, A. (1843). Lecciones de derecho constitucional. Madrid: Imprenta de D. I. Boix.

Andioc, R. (1973). Epistolario de Leandro Fernández de Moratín. Madrid: Castalia.

Aranda Pérez, F. J. y Sanz Camañes, P. (2003). Burgués o ciudadano en la España moderna: una conceptualización historiográfica. En F. J. Aranda Pérez (ed.). Burgueses o ciudadanos en la España moderna (pp. 21-67). Cuenca: Ediciones de la Universidad de Castilla-La Mancha.

Argüelles, A. de. (2011). Discurso preliminar a la Constitución de 1812. Madrid: Centro de Estudios Políticos y Constitucionales.

Bergien, R. y Pröve, R. (comps.) (2010). Spießer, Patrioten, Revolutionäre. Militärische Mobilisierung und gesellschaftliche Ordnung in der Neuzeit. Göttingen: Vandenhoeck und Ruprecht.

Blanco Valdés, R. L. (1988). Rey, Cortes y fuerza armada en los orígenes de la España liberal, 1808-1823. Madrid: Siglo XXI. 
Borreguero Beltrán, C. (1989). Los motines de quintas. Cuadernos de Historia Moderna, 10, 147-159.

Burdiel, I. (1987). La política de los notables: moderados y avanzados durante el régimen del Estatuto Real (1834-36). Valencia: Edicions Alfons el Magnànim.

Caballero, F. (1857). Vida del Excmo. Sr. D. Joaquín María López: Fiscal del Tribunal Supremo de Justicia. Escrita por su amigo intimo Fermin Caballero. Madrid: Imprenta de Manuel Minuesa.

Cabarrús, F. C. de. (1813). Cartas sobre los obstáculos que la naturaleza, la opinión y las leyes oponen a la felicidad pública. Madrid: Collado.

Cabrera, M. A. (2014). El sujeto de la política: naturaleza humana, soberanía y ciudadanía. En M. A. Cabrera y J. Pro (comps.). La creación de las culturas políticas modernas: 18081833 (pp. 37-68). Madrid: Marcial Pons.

Cabrera, M. A. y Pro, J. (comps.) (2014). La creación de las culturas políticas modernas: 18081833. Madrid: Marcial Pons.

Chordá, F., Martín, T. y Rivero, I. (2012). Diccionario de términos históricos y afines. Madrid: Akal.

Chust, M. (1987). Ciudadanos en Armas. La Milicia Nacional en el Pais Valenciano 18341840. Valencia: Editions Alfons el Magnànim.

Chust, M. y Marchena, J. (comps.) (2007). Las armas de la nación: independencia y ciudadania en Hispanoamérica (1750-1850). Madrid: Iberioamericana. Disponible en: https://doi.org/10.31819/9783964565907.

Comellas, J. L. (1963). El Trienio Constitucional. Madrid: Rialp.

Condorcet, J. A. N. de C. (1788). Essai sur la Constitution et les fonctions des Assemblées provinciales (vol. 2). Paris: De k'Imprimerie Royale.

- (1847). Lettres d'un bourgeois de New-Haven à un citoyen de Virginie, sur l'inutilité de partager le pouvoir législatif entre plusieurs corps. En Oeuvres de Condorcet (vol. 9, pp. 3-93). Paris: Firmin Didot Frères, libraires.

Contreras Gay, J. (1993). Las Milicias provinciales en el siglo XVIII: estudio sobre los regimientos de Andalucía. Almería: Instituto de Estudios Almerienses.

Conze, W., Geyer, M., y Stumpf, R. (1978). Militarismus. En O. Brunner, W. Conze y R. Koselleck (comps.). Geschichtliche Grundbegriffe. Historisches Lexikon zur politisch-sozialen Sprache in Deutschland (vol. 4, pp. 1-47). Stuttgart: Klett-Cotta.

Corona Marzol, C. (1999). Las milicias urbanas de la Baja Andalucía en el siglo xviri. En Milicia y sociedad en la baja Andalucía (siglos XVIII y XIX) (pp. 377-390). Madrid: Deimos. (2001). Ciudad y guerra: la movilización del paisanaje (1760-1788). En E. Martínez Ruiz, M. de Pazzis Pi Corrales y J. Torrejón Chaves (comps.). Los ejércitos y las armadas de España y Suecia en una época de cambios (1750-1870) (pp. 377-398). Madrid: Fundación Berndt Wistedt.

- (2009). Las milicias urbanas del siglo XVIII: compañías de reserva y paisanaje. En J. J. Ruiz Ibáñez (comp.). Las milicias del rey de España: sociedad, politica e identidad en las monarquías ibéricas (pp. 437-459). Madrid: Fondo de Cultura Económica.

De la Fuente Monge, G. (2013). La figura del general Espartero en el teatro decimonónico. Historia y Política, 29, 103-138. 
De los Ríos, V. (1792). Instrucción militar Cristiana. Madrid: Imprenta de la Viuda de Ibarra. Escoffet y de Matas, J. (1807). Instrucciones cristianas para los militares. Las públicas corregidas $y$ aumentadas, por Juan Manuel Bedoya. Madrid: Sancha.

Esdaile, C. (2012). Twenty Years On: The Spanish Army in the Peninsular War reprised. En C. Esdaile (comp.). The Spanish army in the Peninsular War. Nottingham: Partizan Press.

Esdaile, C. J. (2004). Fighting Napoleon: Guerrillas, Bandits and Adventurers in Spain, 18081814. London: Yale University Press.

Fernández Cabezón, R. (2007). El teatro político de Félix Enciso Castrillón. En M. del C. García Tejera, I. Morales Sánchez, F. Coca Ramírez, y J. A. Hernández Guerrero (comps.). Lecturas del Pensamiento Filosófico, Estético, y Politico: actas del XIII Encuentro de la Ilustración al Romanticismo (1750-1850) (pp. 53-68). Cádiz: Servicio de Publicaciones de la Universidad de Cádiz.

Fraser, R. (2008). Napoleon's cursed War. Popular resistance in the Peninsular War. London: Verso,

Freire López, A. M. (2008). Entre la ilustración y el romanticismo: la huella de la guerra de la Independencia en la literatura española. Alicante: Servicio de Publicaciones de la Universidad de Alicante. Disponible en: https://doi.org/10.31819/9783954879106.

Frevert, U. (2004). A nation in barracks: Modern Germany, military conscription and civil society. Berg: Oxford.

Fuentes, J. F. (2002). Milicia. En J. F. Fuentes y J. Fernández Sebastián (comps.). Diccionario político y social del siglo XIX español (pp. 443-453). Madrid: Alianza.

- (2007). El fin del Antiguo Régimen (1808-1868): Política y sociedad. Madrid: Síntesis.

García Hurtado, M. R. (2010). La participación de los militares españoles en la prensa del siglo xvirI. Studia Historica. Historia Moderna, 32, 375-398.

- (1997). La tinta y la sangre. Las traducciones de tratados militares franceses en España en el siglo xvini (1700-1808). Ohm: Obradoiro de Historia Moderna, 6, 47-78.

García Pelayo, M. (1964). Mitos y simbolos politicos. Madrid: Taurus.

Gil Novales, A. (1975). Las sociedades patrióticas (1820-1823). Las libertades de expresión y de reunión en el origen de los partidos políticos (vol. 1). Madrid: Tecnos.

Herrero Maté, G. (2003). Liberalismo y Milicia Nacional en Pamplona durante el siglo XIX. Pamplona: Universidad Pública de Navarra.

Hippler, T. (2008). Citizens, Soldiers and National Armies: Military Service in France and Germany 1789-1830. London: Routledge.

Janssen, W. (1982). Krieg. En O. Brunner, W. Conze y R. Koselleck (comps.). Geschichtliche Grundbegriffe. Historisches Lexikon zur politisch-sozialen Sprache in Deutschland (vol. 3). Stuttgart: Klett-Cotta.

Leonhard, J. (2008). Bellizismus und Nation. München: Oldenbourg. Disponible en: https:// doi.org/10.1524/9783486707281.

Llinas, J. A. (1841). Discurso pronunciado por el coronel D. Juan Antonio de Llinás, decano de la Junta Suprema de Vigilancia y Seguridad Pública de Barcelona y diputado provincial, en el acto solemne de derribar la primera piedra de la cortina interior de la Ciudadela en la mañana del 26 de octubre de 1841. Barcelona: Brusi.

López Garrido, D. (1982). La Guardia Civil y los orígenes del Estado centralista. Barcelona: Crítica. 
Luján, O. (2018). Ni tan apáticos ni tan subordinados. Lleida: Editorial Milenio.

Manifiesto de la Milicia Nacional Armada de Barcelona (1841). Imprenta de Constitucional.

Moliner i Prada, A. (1997). Revolución burguesa y movimiento juntero en España. Lleida: Editorial Milenio.

Naranjo Sanguino, M. Á. (2008). La milicia nacional de la ciudad de Badajoz y su marco provincial hasta la disolución de 1844. Badajoz: Diputación de Badajoz.

Oñate Algueró, P. de. (2001). Servir al rey: la milicia provincial (1734-1846). Madrid: Ministerio de Defensa.

Palacios Cerezales, D. (2019). Re-imagining Petitioning in Spain (1808-1823). Social Science History, 43 (3), 487-508. Disponible en: https://doi.org/10.1017/ssh.2019.21.

Pardo Canalís, E. (1951). Escultores del Siglo XIX. Madrid: Instituto Diego Velázquez.

París Martín, Á. (2015). Artesanos y política en Madrid durante el resistible ascenso del liberalismo. Theomai, 31, 43-62.

Pérez Esteves, R. M. (1976). El problema de los vagos en la España del siglo XVIII. Madrid: Confederación Española de Cajas de Ahorros.

Pérez Garzón, J. S. (1975). Los acontecimientos del 7 de julio de 1822. Anales Del Instituto de Estudios Madrileños, 11, 221-235.

(1978). Milicia nacional y revolución burguesa: el prototipo madrileño. Madrid: Consejo Superior de Investigaciones Científicas.

Pérez Ledesma, M. (2007). De súbditos a ciudadanos: una historia de la ciudadanía en España. Madrid: Centro de Estudios Políticos y Constitucionales.

Peyrou, F. (2004). Discursos concurrentes de la ciudadanía: del doceañismo al republicanismo. Historia Contemporánea, 28, 267-283.

Portet i Pujol, J. (2003). La milicia nacional de Vic durant la primera guerra carlina. Vic: Patronat d'Estudis Osonencs.

Roca Vernet, J. (2020). La milicia nacional o la ciudadanía armada. El contrapoder revolucionario frente al liberalismo institucional. Bulletin d'Histoire Contemporaine de l'Espagne, 54, 105-125. Disponible en: https://doi.org/10.4000/bhce.2598.

Romero, M. C. (1993). Entre orden y la revolución. Alicante: Instituto de cultura Juan Gil-Albert.

(1998). Lenguaje y política del nuevo liberalismo: moderados y progresistas, 18341845. Ayer, 29, 37-62.

Rousseau, J. J. (1971). Considerations sur le gouvernement de la Pologne et sur sa réformation projetée (1770-1771). Oeuvre complètes (vol. 3). Paris: Seuil.

Ruiz, A. (s. f.). Respuesta al pretendido reformador de la Milicia Urbana de Madrid. Imprenta de Collado.

Ruiz de Morales, J. (1855). Historia de la milicia nacional: desde su creación hasta nuestros dias. Madrid: Prats y Ruiz.

Ruiz Ibáńez, J. J. (1996). Sujets et citoyens: Les relations entre l'Etat, la ville, la bourgeoisie et les institutions militaires municipale à Murcie (XVIe-XVIIe siècle). En M. Boone y M. Prak (comps.) Status individuels, status corporatifs et status judiciaries dans les villes européennes (pp. 129-157). Leuven: Garant.

Ruiz Ibáńez, J. J. (2009). Repúblicas en armas: Huestes urbanas y ritual político en los siglos XVI y xvir. Studia Historica. Historia Moderna, 31, 95-125. 
Rújula López, P. (1998). Contrarrevolución: realismo y carlismo en Aragón y el Maestrazgo, 1820-1840. Zaragoza: Prensas Universitarias de Zaragoza.

Santirso Rodríguez, M. (1995). Voluntarios realistas, voluntarios de Isabel II y Milicia nacional, o en la guerra también hay clases (Cataluña, 1832-1837). Historia Social, 23, 21-40.

Sierra, M. (2000). Electores y ciudadanos en los proyectos políticos del liberalismo moderado y progresista. En M. Pérez Ledesma (dir.). De súbditos a ciudadanos. Una historia de la ciudadania en España (pp. 103-133). Madrid: Centro de Estudios Políticos y Constitucionales.

Solís, R. (2012). El Cádiz de las Cortes. La vida en la ciudad en los años 1810 a 1813. Madrid: Silex.

Suárez, F. (comp.) (1967a). Cortes de Cádiz. Informes oficiales sobre Cortes (vol. 1). Baleares. Pamplona: Universidad de Navarra.

(1967b). Estudio preliminar. En F. Suarez (comp.). Cortes de Cádiz. Informes oficiales sobre Cortes (vol. 1). Baleares. Pamplona: Universidad de Navarra.

- (comp.) (1974). Cortes de Cádiz. Informes oficiales sobre Cortes (vol. 3). Andalucia y Extremadura. Pamplona: Universidad de Navarra.

Tusell, J. (1976). Oligarquía y caciquismo en Andalucía (1890-1923). Barcelona: Editorial Planeta.

Una reunión de amigos colaboradores (1845). Panorama Español, crónica contemporánea. Obra pintoresca (vol. 3). Madrid: Panorama Español.

Vallverdú i Martí, R. (1989). El suport de la Milicia nacional a la revolució burgesa a Reus. Lleida: Virgili y Pagés.

Varela Ortega, J. (1977). Los amigos politicos: partidos, elecciones y caciquismo en la Restauración (1875-1900). Madrid: Alianza. 